\title{
Лікування поєднаної патологіі анального каналу і прямої кишки з використанням електрохірургічного високочастотного апарата «ЕФА»
}

\author{
М. П. Захараш ${ }^{1}$, В. В. Балицький ${ }^{2,3}$, О. Г. Курик ${ }^{4}$ \\ ${ }^{1}$ Національний медичний університет імені О. О. Богомольця, м. Київ, \\ ${ }^{2}$ Вінницький національний медичний університет імені М. І. Пирогова, \\ ${ }^{3}$ Хмельницька обласна лікарня, \\ ${ }^{4}$ Науково-практичний центр профілактичної та клінічної медицини, м. Київ

\section{The treatment of concomitant pathology of anal channel and rectum, using electro-surgical high-frequency apparatus «EFA»}

\author{
M. P. Zakharash ${ }^{1}$, V. V. Balytskyy ${ }^{2,3}$, O. G. Kuryk ${ }^{4}$ \\ ${ }^{1}$ Bogomolets National Medical University, Kyiv, \\ ${ }^{2}$ Pyrogov Memorial National Medical University, Vinnytsya, \\ ${ }^{3}$ Khmelnytskyi Regional Hospital, \\ ${ }^{4}$ Scientific-Practical Centre of Prophylactic and Clinical Medicine, Kyiv
}

Реферат

Мета. Покращення результатів хірургічного лікування хворих з поєднаною патологією анального каналу і прямої кишки шляхом використання електрохірургічного високочастотного апарата «ЕФА».

Матеріали і методи. Проаналізовано результати лікування 114 пацієнтів 3 поєднаною патологією анального каналу прямої кишки з використанням електрохірургічного високочастотного апарата «ЕФА».

Результати. Встановлено, що у разі використання електрохірургічного високочастотного апарата «ЕФА» тривалість операції зменшується до (25 \pm 5$)$ хв, об'єм крововтрати - до $(20 \pm 5)$ мл, потреба в наркотичних аналгетиках - до $(3 \pm 1)$ мл, тривалість стаціонарного лікування - до (6 61$)$ доба.

Висновки. Використання електрохірургічного високочастотного апарата «ЕФА» приводить до скорочення тривалості операції, зменшення об'єму є інтраопераційної крововтрати, інтенсивності больового синдрому в післяопераційному періоді. Після використання даної хірургічної технології глибина некрозу тканин незначна - $(0,254 \pm 0,18$ мм $)$, чим забезпечуеться косметичність операції.

Ключові слова: поєднана патологія; анальний канал; пряма кишка; електрохірургічний високочастотний апарат «ЕФА»

Abstract

Objective. To improve the results of surgical treatment in patients with concomitant pathology of anal channel and rectum, using electro-surgical high-frequency apparatus «EFA».

Materials and methods. The results of treatment of 114 patients with concomitant pathology of anal channel and rectum, using electro-surgical high-frequency apparatus «EFA», were analyzed.

Results. There was established, that while application of electric high-frequency apparatus «EFA» the operation duration diminishes down to $(25 \pm 5) \mathrm{min}$, the blood loss volume - to $(20 \pm 5) \mathrm{ml}$, the need for narcotic analgetics - to $(3 \pm 1) \mathrm{ml}$, a stationary treatment stay - to $(6 \pm 1)$ days.

Conclusion. Application of electro-surgical high-frequency apparatus «EFA» leads to the operation duration shortening, its volume and the intraoperative blood loss restriction, reduction of the pain syndrome intensity in postoperative period. After application of this surgical technology the tissues necrosis depth is not significant $-(0.254 \pm 0.18 \mathrm{~mm})$, thus providing the operation cosmetics.

Keywords: concomitant pathology; anal channel; rectum; electro-surgical high-frequency apparatus «EFA».

Частота проктологічних захворювань стрімко зростає, а єдиного підходу до хірургічного лікування цієї категорії пацієнтів не напрацьовано. Крім того, публікацій з результатами наукових досліджень, присвячених вивченню проблеми поєднаної патології анального каналу і прямої кишки, досить мало [1].

У разі поєднаної патології анального каналу і прямої кишки найчастіше констатують комбінацію таких захворювань: геморой і анальна тріщина (51,8 - 58,4\% спостережень), геморой і хронічний парапроктит (19 - 81\%), геморой і гострий парапроктит (1,2 - 3\%), геморой і поліп прямої кишки $(10,1-14,3 \%)[2,3]$.
Упродовж останнього десятиліття в лікуванні хронічного геморою III - IV стадії, поєднаного з іншою патологією анального каналу і прямої кишки, широко застосовують «гібридні» операції [4], які передбачають деартеріліазацію гемороїдальних вузлів з мукопексією або їх латексне лігування, ліфтинг та мукопексію з видаленням супутньої патології анального каналу [5 - 7]. Безпосередні та віддалені анатомічні і функціональні результати хірургічного лікування із застосуванням оперативних втручань як геморою, так і супутньої аноректальної патології значно кращі, але воно, на жаль, не позбавлено недоліків, у тому числі ускладнень, таких як тромбоз зовнішнього гемо- 
роїдального вузла (2 - 5,8\% спостережень), гостра анальна тріщина (2\%), післяопераційна кровотеча (1 - 2\%), випадіння гемороїдальних вузлів (6,6\%), формування гіпертрофованих періанальних шкірних міток (75\%), анальний свербіж (15,2\%) [8 - 10].

Отже, актуальність проблеми поєднаної патології анального каналу і прямої кишки спонукає до напрацювання і впровадження в клінічну практику нових високоефективних методів хірургічного лікування даної категорії хворих, які б не приводили до розвитку у них ускладнень в післяопераційному періоді і забезпечували їх швидку медико-соціальну реабілітацію.

Мета дослідження: покращення результатів хірургічного лікування пацієнтів з поєднаною патологією анального каналу і прямої кишки шляхом використання електрохірургічного високочастотного апарата «ЕФА».

\section{Матеріали і методи дослідження}

Із січня 2007 по грудень 2017 р. у відділенні проктології Хмельницької обласної лікарні прооперовано 114 пацієнтів з поєднаною патологією анального каналу і прямої кишки з використанням електрохірургічного високочастотного апарата «ЕФА» (досліджувана група). Чоловіків було 65 (57\%), жінок - 49 (43\%). Вік пацієнтів коливався від 24 до 72 років.

Оперативні втручання всім пацієнтам досліджуваної групи виконували з використанням електрохірургічного високочастотного апарата «ЕФА» російського виробництва (ТОВ «ЭФА», м. Санкт-Петербург), оснащеного системою адаптивного регулювання вихідної високочастотної напруги в залежності від опору тканини зі стабілізацією вихідної потужності 200 Вт і частоти 375 кГц у широкому діапазоні навантажень - від 100 до 2000 Ом. Ця унікальна особливість приладу дає можливість здійснювати електротомію та електрокоагуляцію з максимальним ефектом та мінімальним некрозом тканин, а також використовувати його в рідинних середовищах. Апарат має шість основних режимів роботи з незалежним регулюванням потужності, що уможливлює обирати під час операції найбільш зручний режим для конкретного хірургічного втручання.

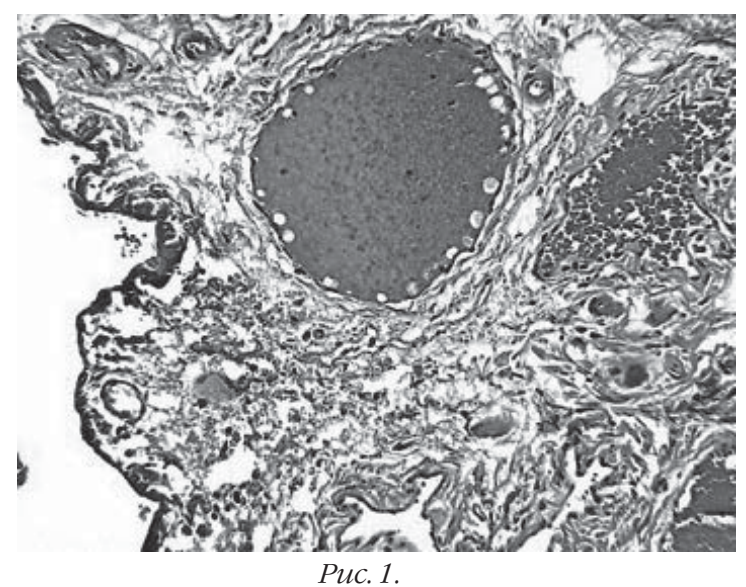

Мікрофото. Збереження тканинної структури з утворенням тонкого шару коагуляційного некрозу після використання електрохірургічного методу.

Забарвлення гематоксиліном і еозином. $36 . \times 100$.
Контрольну групу склали 112 пацієнтів з поєднаною патологією анального каналу і прямої кишки, оперованих стандартно без використання електрохірургічного високочастотного апарата.

Всі оперативні втручання виконані під спинномозковою анестезією. Всім пацієнтам перед операцією проведено огляд періанальної і параректальної ділянок, пальцеве дослідження анального каналу і прямої кишки, ректороманоскопію. 3 метою дообстеження і виключення патології ободової кишки 51 (45\%) пацієнту у віці старше 45 років було виконано іригоскопію або фіброколоноскопію.

Після оперативних втручань з використанням електрохірургічного високочастотного апарата «ЕФА» проводили морфологічне дослідження тканин з метою вивчення глибини їх некрозу. Для порівняння використовували операційний матеріал, отриманий під час операцій із застосуванням хірургічного металевого скальпеля.

Операційний матеріал фіксували у $10 \%$ розчині нейтрального формаліну. Далі його обробляли в гістопроцесорі карусельного типу STP 120. Для виготовлення парафінових блоків використовували станцію ЕС-350, їх зрізів - ротаційний мікротом серії НM 340Е, для фарбування гістологічних препаратів - автомат HMS740 «RobotStainer» (всі апарати фірми Carl Zeiss MICROM International $\mathrm{GmbH}$, Німеччина). Препарати фарбували гематоксиліном і еозином. Використовували мікроскоп Axioskop 40 3 фотокамерою Axio Cam MRc5 (Karl Zeiss).

\section{Результати}

У 85 (74,6\%) пацієнтів досліджуваної групи виявлено два захворювання, у 26 (22,8\%) - три захворювання, у 3 (2,6\%) - чотири захворювання анального каналу і прямої кишки. Найчастіше спостерігали такі варіанти поєднаної патології анального каналу і прямої кишки: хронічна анальна тріщина і анальний поліп - у 27 (23,7\%) пацієнтів, хронічна анальна тріщина і комбінований геморой - у 22 (19,3\%), комбінований геморой і хронічний парапроктит - у 18 (15,8\%), комбінований геморой і анальний поліп - у 15 (13,1\%), хронічна анальна тріщина, анальний поліп і гіпертрофовані періанальні шкірні мітки - у 8 (7,0\%), комбінований геморой, хронічна анальна тріщи-

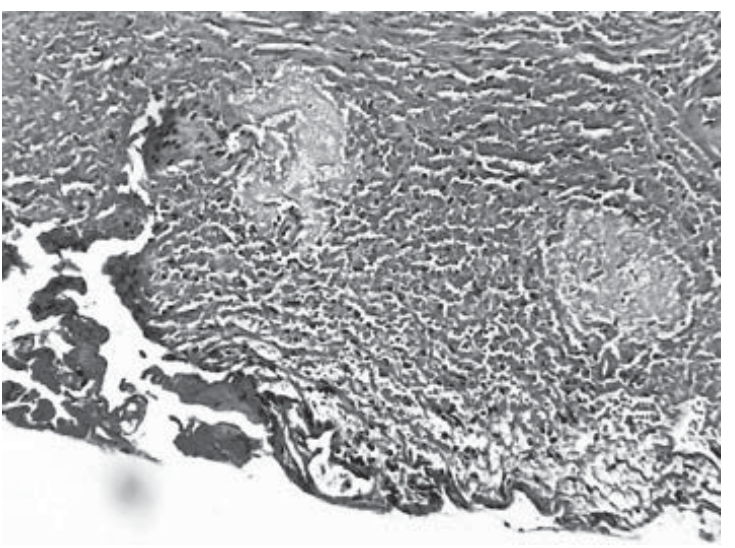

Puc. 2 .

Мікрофото. Край рани після використання металевого скальпеля: поширені крововиливи. Забарвлення гематоксиліном і еозином. $36 . \times 100$. 
на і анальний поліп - у 8 (7,0\%), зовнішній геморой і хронічний парапроктит - у 6 (5,3\%), хронічний парапроктит і анальний поліп - у 6 (5,3\%), хронічний внутрішній геморой III стадії і хронічна анальна тріщина - у 4 (3,2\%).

Характер виконаних оперативних втручань залежав від варіанта поєднаної патології анального каналу і прямої кишки. Найчастіше застосовували такі комбінації оперативних втручань: висічення анальної тріщини і поліпектомія - у 27 (23,7\%) пацієнтів, висічення анальної тріщини і гемороїдектомія - у 22 (19,3\%), гемороїдектомія і висічення анальної фістули - у 18 (15,8\%), гемороїдектомія і поліпектомія - у 15 (13,2\%), висічення анальної тріщини, поліпектомія, електроексцизія гіпертрофованої періанальної шкірної мітки - у 8 (7,0\%), гемороїдектомія, висічення анальної тріщини, поліпектомія - у 8 (7,0\%), гемороїдектомія і висічення анальної фістули - у 6 (5,3\%), висічення анальної фістули і поліпектомія - у 6 (5,3\%), гемороїдектомія і висічення анальної тріщини - у 4 (3,5\%).

Проведеним дослідженням встановлено, що у разі використання електрохірургічного високочастотного апарата «ЕФА» тривалість операції становила в середньому $(25 \pm 5)$ хв, об'єм крововтрати - $(20 \pm 5)$ мл, в контрольній групі - $(30 \pm 5)$ хв та $(40 \pm 10)$ мл відповідно. Больовий синдром у післяопераційному періоді був більш виражений у пацієнтів контрольної групи, вони потребували для знеболювання (4 \pm 1 ) мл наркотичних засобів, а пацієн-

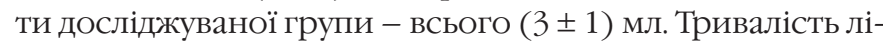
кування у стаціонарі пацієнтів досліджуваної групи ста-

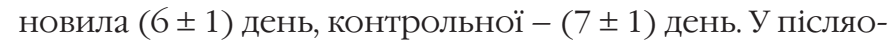
пераційному періоді у пацієнтів досліджуваної групи не виявили ознак недостатності анального сфінктера, а також формування рубцевої стриктури анального каналу. У 4 (3,6\%) пацієнтів контрольної групи сформувалась рубцева стриктура анального каналу, у зв'язку з чим у 2 із них застосували консервативні, у 2 - оперативні заходи. За даними морфологічного дослідження встановлено, що у разі використання електрохірургічного високочастотного апарата «ЕФА» під час розрізу тканин відбувалися їх розсічення і коагуляція з контролем гемостазу та утворенням шару коагуляційного некрозу, середня товщина якого становила $(0,254 \pm 0,18)$ мм (рис. 1). Використання хірургічного металевого скальпеля призводило до травматизації і крововиливів у краях операційної рани, що в подальшому уповільнювало їі загоєння (рис. 2).

\section{Обговорення}

Застосування електрохірургічного високочастотного апарата «ЕФА» у лікуванні хворих з поєднаною патологією анального каналу і прямої кишки приводило до зменшення тривалості оперативних втручань, яка становила в середньому (25 \pm 5$)$ хв, зменшення вдвічі об'єму крововтрати під час операції, яка становила в середньому (20 \pm 5) мл.

Після використання електрохірургічного високочастотного апарата «ЕФА» в тканинах утворювався шар коагуляційного некрозу, середня товщина якого становила $(0,254 \pm 0,18)$ мм, завдяки чому у пацієнтів вдвічі меншим був больовий синдром і вони потребували вдвічі менше наркотичних засобів для знеболювання порівняно 3 контрольною групою.
Застосування хірургічного металевого скальпеля супроводжувалось утворенням поширених крововиливів у тканинах, що обумовлювало їх більшу травматизацію і більш виражений больовий синдром у пацієнтів.

Після використання електрохірургічного високочастотного апарата «ЕФА», оскільки вплив на тканину був мінімальним, формувався косметичний післяопераційний рубець, не виникали рубцеві стриктури анального каналу, а також скоріше загоювалися рани, що обумовлювало швидшу реабілітацію пацієнтів.

\section{Висновки}

1. У разі використання електрохірургічного високочастотного апарата «ЕФА» скорочується тривалість операції, вдвічі зменшується об'єм інтраопераційної крововтрати та інтенсивність больового синдрому в післяопераційному періоді, також скорочуються строки лікування пацієнтів, що обумовлює їх швидку медико-соціальну реабілітацію.

2. Застосування методики лікування з використанням електрохірургічного високочастотного апарата «ЕФА» $€$ значно кращим порівняно з використанням хірургічного металевого скальпеля, оскільки забезпечує швидше загоєння післяопераційної рани з формуванням ніжного еластичного рубця, що запобігає виникненню рубцевих стриктур та недостатності анального сфінктера в післяопераційному періоді.

\section{References}

1. Raiymbekov OR, Attokurov BK, Zholbolduev ZhM. Rezul'taty hirurgicheskogo lechenija anal'noi treshhiny v sochetanii s hronicheskim gemorroem. Koloproctologia Prilozhenie. 2016;(2):39-40. [In Russian].

2. Borota AV, Kuhto AP, Hul'mamedov VA, Borota AA, Bashmakov MN, Baziyan- Kuhto NK, Fedoryshyn AA. Khirurhicheskoe lechenie sochetannoi neopukholevoi patologii anorektal'noi zony. 2017.10.26-28; Voronezh. Koloproctologia. 2017;(3):17-8.[In Russian].

3. Rajymbekov OR, Zholbolduev ZhM, Ajdarov UA. Sovremennye vzgljady na diagnostiku i lechenie pararektal'nogo svishha v sochetanii s hronicheskim gemorroem. Koloproctologia. 2017;(3):37-8.[In Russian].

4. Belotskaya LV, Chistokhin SY. Gibridnye operatsii pri khronicheskom gemorroe. Koloproctologia Prilozhenie. 2016;(2):14-5. [In Russian].

5. Pyrohovskyi VIu, Sorokin BV, Feleshtynskyi IaP, Zadorozhniy SP, Taranenko AO, Zlobenets SO, Noies AJ. Dosvid vykorystannia THD v kombinatsii z vysichenniam analnoi trishchyny. Klinichna khirurhiia. 2016;910(3):86. [In Ukrainian].

6. Rafibekov ED, Subanov AA, Aisaev AA. HAL-RAR pri lechenii gemorroia 3-4 stadii v sochetanii s soputstvuyushchei anal'noy patologiyey. In: II siezd koloproktologov stran SNG, III siezd koloproktologov Ukrainy. Materialy siezdjv. Kiev: Publish centre Image of Ukraine; 2011:504-5. [In Russian].

7. Shamaeva TE, Nikishina TG, Chukardin AV, Jakimov SA. Hirurgicheskoe lechenie anal'noj treshhiny pri sochetanii s hronicheskim gemorroem. Koloproctologia. 2017;(3):48-9.[In Russian].

8. Groshilin VS, Cherkasov MF, Mirzoev LA, Mryhin GA. Korrekcija pokazanij k primeneniju metodov maloinvazivnogo lechenija gemorroja s uchjotom sovershenstvovanija tehnologij. Koloproctologia. 2017;(3):20. [In Russian].

9. Pleshkov AS.Opyt primenenija metodiki HAL-RAR pri lechenii gemorroidal'noj bolezni v stacionare "odnogo dnja". Koloproctologia. 2017;(3):36-7.[In Russian].

10. Chistohin SJu, Belockaja LV. Rezul'taty razlichnyh operacij pri gemorroe. Koloproctologia. 2017;(3):47-8.[In Russian]. 